\title{
An Overview of Comparison between Construction Contracts in Malaysia: The Roles and Responsibilities of Contract Administrator in Achieving Final Account Closing Success
}

\author{
Zarabizan bin Zakaria, Syuhaida binti Ismail \\ RAZAK School of Engineering and Advanced Technology, \\ University Technology Malaysia \\ Jalan Semarak, 54100 Kuala Lumpur, Malaysia
}

\author{
Aminah binti Md Yusof \\ Faculty of Civil Engineering, University Technology \\ Malaysia, 81310 UTM, Johor, Malaysia
}

\begin{abstract}
The administration of construction contracts in Malaysia is facilitated through a standard form of contract. The application of each however depends on the type of project, mode of finance and owner of the project. International Federation of Consulting Engineers (FIDIC), Public Work Department 203A (PWD203A), Pertubuhan Akitek Malaysia (PAM) Standards form of contract are widely implemented in Malaysia. In generally, each standard form of contract aims at ensuring effective, efficient and non-disputable contract administration. Nonetheless, variations arise in certain matters. This paper appraises the differences in roles and responsibilities of contract administrator as stipulated in each forms, namely PWD203A, PAM and FIDIC via literature review on some different types of forms of contract used in Malaysia. This aim can be achieved by determining the important factors affecting final account closing success caused by contract administrator, and investigating the differences between forms of contract. The understanding of these roles and responsibilities is important at the preliminary stage especially in selecting superintending party as well as identifying the contract liability in the persuasion of the contract. This paper shows that the use of contract documents either FIDIC, PAM and PWD 203A is dependent on the project owner/employer, type of project as well as the nature of a project and financing involved. Most of the projects under the government will apply PWD203A contract document while the private sector will use PAM contract document and FIDIC contract document will be used for projects involving international contracts.
\end{abstract}

Keywords- Roles \& responsibilities, contract administrator, project management, standards forms of contract, final account closing

\section{INTRODUCTION}

The construction industry in this country is one of the nation outcome areas and is also a contributor to the country's economic performance (Moavenzadeh, 1975). Low (1994) argues that the construction industry has a direct bearing on the national economy and consequently, can be used as an indicator of economic well-being for a country. The construction industry is an industry that consists of construction of building structures such as roads and bridges. The construction industry is not only about making buildings, but also about repairing the breaks and keeping the building to be safe (Hillebrandt, 2004). Construction industry also includes metal work, electrical, mechanical, architectural and other related construction projects to ensure that plan is to be completed successfully. The construction industry is conventionally fraught with the adversarial working relationships between contracting parties, particularly in case of competitive fixed-price lump-sum contracts (Kaka et al., 2008).The construction industry can be categorized into several sectors of offices, shops, houses, infrastructure and industry (Merrit and Ricketts, 2004).

The construction sector accounted for nearly 3.3 percent of Gross Domestic Product (GDP) in 2005 and a total of 109,000 foreign workers from approximately 600,000 employed in Malaysia (MALBEX, 2005). The contribution of the construction industry to GDP is also affected by various initiatives by the government in attracting foreign investors to contribute to the existence of new buildings in Malaysia. Thus, the effect of construction on the economy through the production process and through the effects of credit constraint can be as important as the effect of the economy on the construction sector (Tse, 1997). Therefore, the construction industry is considered as a promoter of the development of other industries. The categories of buildings to be constructed should be considered based on the client's needs.

Construction industry can be categorized as high risk as it is very complex and involve a variety of business sectors. The construction industry is one of the complex industries and a challenging field, hence it needs to be done properly and wisely to avoid the emergence of problems that can affect the overall project. Besides, the nature of the complex construction industry also requires an efficient work process and a strong relationship between the parties involved in the construction industry. This is due to the fact that complex disputes will occur in a situation in such a complex project, which are predominantly arisen from the intricacy and the 
magnitude of the work, multiple prime contracting parties, poorly prepared, understanding role and responsibilities, and/or executed contract documents, inadequate planning, financing issue, and communication problems (Abdalla and Hussien, 2001). This is supported by Merrit and Ricketts (2004) who claim that a high level of organizational complexity in the construction industry, as many specialized skills and professions contribute to the complexity in the construction process. Any one of these factors can derail a project and lead to complicated litigation or arbitration, increased costs, and breakdown in parties' communication and relationship (Harmon, 2003). Furthermore, the causes of dispute are all because of the complexity and nature of the project, contract and the contractual relationship between each other that consequently lead to misunderstanding and failure of performing (Hellard, 1997). Murali (2006) identifies that lack of communication between parties is one of the causes and effects of delays faced by Malaysia construction industry player. This is basically happening because the contract administrator does play their role very well.

According to Whitfield (1994), the construction is a rare industry that produces so many varied products without significant repetition. The industry is enriched by the presence of other parties. It is this variety of interests that provides the catalyst for conflict hence dispute in the construction industry. Dispute in construction has been characterized mainly by its natures as diverse business and it covers a wide range of end products and people working for a broad range of crafts and professional. In managing the conflict in the construction industry, various methods have been implemented. The use of standard form of contract can reduce the dispute or conflicts from occurring such as via the use of traditional system. The standard methods of measurement and co-ordinated project information are all essential to the smooth functioning of the traditional system (Cherns and Bryant, 1984).

Normally, disputes arise due to problems in making the evaluation process and understanding the contents of the construction contract conditions. Disputes arise when no consensus is reached as specified in the contract. According to Yogeswaran et al. (1998), the construction dispute is mainly related to contractual matters, including variation, extension of time, payment, quality of technical specifications, availability of information, administration and management and determination. In construction industry, disputes are not something that can be easily eliminated since the circumstances in construction are fraught with risks. For example, a weak understanding of contract documents will causes of the risks occur (Thomas et al. 1994). On the contrary, the problem is caused by the legal understanding (Martin, 1993) and explanation of the contract clauses (Cheung, 1999), which has greatly contributed to the dispute especially regarding contractual obligation. However, through better interpretation and understanding of the contract clauses especially on role and responsibilities, the dispute arose may be eliminated.

The contract documents which apply either in government or private projects are dependent on the understanding and complexity of the parties involved. Mohamad and Zulkifli (2006) state that there is a lack of understanding of the content specified in the contract documents, thus suggest means to improve the understanding of contract by regular training for contractors, engaging qualified personnel, clarifying in the contract document itself, and the using of simple language. Hence, better training in the area of contract management to the professionals can be said to be of a great help in better understanding of the contract (Iyer, 2007).

Having conferred the medical perspectives, the statement of "prevention is better than cure' is merely a strategy or method of treatment. However, it is viewed from the perspective of construction, it means that the contents of the contract documents are easily explained to provide a better understanding in order to minimize disputes that may occur. Yet, for construction dispute, it is applicable and extremely suitable for a dispute resolution prevention technique. According to Rubin et al. (1992), the focus on prevention methods or techniques towards the occurrence of a dispute should become as a part of minimization effort. Hence, it is observed by this paper that although the construction contract can be considered as a source of construction dispute in the event of misunderstanding and ignorance of the contract clauses, it also provides a platform for construction parties to avoid the disputes from happening. They also demonstrated consistency of the law several cases because of negligence to understand term contract, namely disputes on misunderstanding (Thomas, 1992) and disputes on interpretation of clauses (Thomas, 1994).

Therefore, the interrelation and better understanding of the content relating to the duties and responsibilities of the contract can act as a means of preventing settlement of the dispute within the jurisdiction of a particular contract administrator. According to Cheung (1999), the determination of the dispute resolution method of prevention will create a teamwork environment. It can prevent disputes from arising. However, that solution does not guarantee full removal of the dispute, but it is still said to be good for reducing disputes over the duties and responsibilities of contract administrators.

Basically, the construction industry is highly fragmented (Mitropoulos and Taum, 2000) in terms of its processes due to the working relationship, communication, role and responsibilities as well as contractual commitment, which are often being carried out in the good faith. The situation has apparently led to the adversarial approaches to public and private sector in the construction industry (Thompson, Vorster and Groton, 2000). Thus, in the event of non-good faith or breach, there are clauses provided for employers to determine the contract according to the reasons as stated (Che Rozilawani, 2003). Nevertheless, the issue on who can determine whom for example, has not been well understood. Normally, some of the contractors are unfamiliar with the clauses provided under the contract used in the project. It is, therefore important to create awareness among the key players in the construction on all clauses available in the standard forms of contract. Mbachu and Nkado (2007) identify factors relating to the acts or omissions of the key role players including clients, consultants and contractors, as well as project 
characteristic and external factors. Apart from creating this awareness, it can be used as a basic guidance for those involved in the construction industry to better understand the clauses provided under the contract, thus unnecessary disputes can be avoided in assuring the project success and tying-up better relationship among the contractual parties. Hence, this paper intends to determine some problems related to this poor understanding of contract terms and conditions with a particular reference to standard contract which has been used widely in Malaysia. Hence, this paper intends to enhance understanding of the roles and responsibilities as a contract administrator in preventing the occurrences of dispute in the contract causing, project delay, arbitration cases, litigation issues and settlement of the closing of final account which cannot be done within the time frame. This paper will also describe the contents forms of contract that are used in the construction industry in Malaysia.

\section{OVERVIEW OF STANDARD CONSTRUCTION CONTRACT IN MALAYSIA}

Administration of a contract is necessary to ensure effectiveness. Administration of a contract means to ensure that the contract is performed according to the articles of agreement and conditions of contract and within the framework of related laws and the practices of the construction industry. In Malaysia, there are several standard forms of contract, namely Pertubuhan Akitek Malaysia (PAM), Public Works Department (PWD) and International Federation of Consulting Engineers (FIDIC). The use of each, however subject to type of project, the nature of a project and financing involved. For instance, Wilkinson and Scofield (2010) identify the choice of procurement system as having significant impact on the achievement of time, cost and quality targets for a project. In the construction industry, the standard form of contract is one of the key methods of ameliorating a potentially fractions relationship to achieve a common end. It evidences the legal relationship between the parties in the contract and provides the administrative procedures necessary for realization of the legal relationship. Any standard form of contract would need to appreciate and incorporate all the special requirements and circumstances that a project would call for. A standard form of construction contract would therefore be useful in expressing the obligation of the parties and setting out the reasonable clarity the scope of the project (PAM, 2006). The selected standard forms of contract in this paper are discussed in the succeeding section.

\section{A. FIDIC (International Federation of Consulting Engineers)}

FIDIC stands for International Federation of Consulting Engineers which its headquarters located in Geneva, Switzerland. FIDIC documents are recommended for building or engineering works designed by the employer, or by his representative, the engineer (Mushtaq, 2007). Under the usual arrangements for this type of contract, the contractor constructs the works in accordance with the design provided by the employer. However, the works may include some elements of Contractor - designed, civil, mechanical, and electrical and/or construction works.
The parties involved in FIDIC contract documents are contracting authority/employer, contractor which is a contract between employer, an engineer appointed to administer the FIDIC Contract on behalf of the employer. FIDIC conditions of contract has been applied worldwide, especially in the projects invested/financed by the World Bank, Asia Development Bank, African Development Bank etc. The FIDIC contract comprises four standard forms of contract namely FIDIC Conditions of Contract for Construction (Red Book), FIDIC Conditions of Contract for Plant and Design/Build, FIDIC Conditions of Contract for EPC Turnkey Projects (Silver) and FIDIC Short Form of Contract the Green Book.

The FIDIC Short Form of Contract is recommended for engineering and building work of relatively small capital value, fairly simple or repetitive work or work of short duration without the need for specialist subcontracts (Broome and Hayes, 1997). The parties involved in the contract are the employer and contractor. The Short Form permits the employer to nominate his authorised spokesman and provides no overall limit on the contractor's liability.

Employer liabilities provided for in the Short Contract include any operation of the forces of nature affecting the site and/or works, which was not foreseeable. It also states physical obstructions or physical conditions other than climatic conditions encountered on the site during the performance of the works, which obstructions or conditions were not reasonably foreseeable by an experienced contractor. This contract also explains that the damage cannot be avoided result of the obligation the contractor to remedy defects.

The Short Form of Contract makes reference to an appendix in which it is stated whether the work is to be valued and paid for on the basis of lump sum price, lump sum price with schedule of rates, lump sum price with bill of quantities, remeasurement with tender bill of quantities or cost reimbursable. Payments are made on a monthly assessment submitted by the contractor for the employer to pay the amount he considers due. A final account is then submitted by the contractor to the employer for him to ascertain the final contract value.

As per clause 1 in any FIDIC standard form, the engineer and his representatives (assistants and inspectors named under FIDIC versions to represent the engineer) are two different entities. The engineer's representative is appointed by the employer to perform the duties delegated under another clause (clause 3 under new forms). This clause sets out the duties of the engineer's representative, basically to watch and supervise works, and test and examine materials to be used and workmanship employed in connection with the works. However, the engineer's representative has no authority to relieve the contractor of any duties or obligations under the contract except as expressly provided in the contract, order any work involving delay or extra payment, and make any variation. The engineer also cannot amend the contract.

In summary, it can be said that FIDIC is a 'measure and value' contract, which is fundamentally derived from the Institute of Civil Engineers (ICE) condition of a contract for the use on civil engineering works. Under FIDIC, any 
decisions on matters in dispute are resolved by the Dispute Adjudication Board (DAB) and disputes which are not satisfied by a decision of the $\mathrm{DAB}$ are required to be attempted to be settled amicably before arbitration in commercial if necessary (FIDIC, 1999).

\section{B. PWD 203A (Public Works Department)}

Public Works Department of Malaysia (PWD) is a government agency that responsible for the forms of contracts PWD203A. These are the traditional forms of contract based on bills of quantities (203A) produced for the use in the public sector or government projects in both building and civil engineering contracts. PWD Contract forms are the home based forms where risks are known to the local industry, whereas a lump sum contract, it is incorporated with either bills of quantities or schedule of rates (PWD 203A, 2007). In this type of contract, there is a separation of construction and design where the designing team is contracted by the client, and they shall provide the contractor with a complete design (Ashworth, 1991). Generally, it can be said that the majority of the risks have been transferred to the contractor under these standard forms of contract and this remains true with the latest 2007 version.

Under Condition of Contract PWD Form203A, the Superintendent Officer (S.O.'s) duties involves the overall supervision and directions of the works encompassing the important decision on the Damages For Non-Completion (Clause 40), Delay and Extension Of Time (Clause 43), Events and Consequences of Default by the Contractor (Clause 51), Termination on Corruption (Clause 53), Effect of Force Majeure (Clause 57) or Arbitration (Clause 65), where appropriate, are expressly reserved to the Appendix (usually a person more senior than the S.O) which are stated in Clause 3.0, 4.0 and 5.0.

According to Fahime, Zuhairuse and Muhammad Farihan (2011), the important aspect in PWD 203A is bills of quantities where the project manager controls and monitors the work through the schedule of planning during construction. Therefore, the contractor has the responsibility to complete the work according to the requested quantities referred to the contract documents. In PWD 203A, the government is entitled to deduct such costs, expenses and on-cost charges or any part of any monies due to the contractor or to recover it from performance bond as a debt due from the contractor. This drives to the popularity of PWD203A procurement in the public's in Malaysia.

\section{PAM (Pertubuhan Akitek Malaysia)}

The PAM standard form of contract has been widely used by the Malaysia Building Industry over the last 40 years. PAM undertook a complete revamp of the PAM 1969 Form which was replaced by the PAM 1998 Form. The PAM 1998 Form was extensively employed in the building industry in Malaysia but was subjected to criticism by a segment of the said industry. The above necessitated a further review, which culminated in the drafting and implementation of the latest revised form entitled "The PAM Contract 2006". The latter form has been officially launched and intended by PAM to replace the earlier 1998 PAM. It is estimated that 90 per cent of the building contracts in the private sector are based on the PAM form (Sundra, 2010). PAM form is home base form where the risks are known to be local industry and intended to be used as a building contractor and not as a civil engineering contract (PAM, 2006).

In summary, it seems clear that the selection forms of contract is a crucial factor in the performance of a construction project. It shows that the use of contract documents either FIDIC, PAM and PWD 203A is dependent on the project owner/employer, type of project as well as the nature of a project and financing involved. The understanding of the contents of forms of contract can assist the parties who involved in managing projects to be more effective and efficient. In fact, consciousness understanding the problem is caused by legalese (Martin, 1993). From this study, it is found that the Standard Form construction contracts provide a basic legal framework identifying the rights, obligations and duties of the parties as well as establish the ambit of the powers and duties of the contract administrator.

III. COMPARISONS OF ROLES AND RESPONSIBILITIES OF CONTRACT ADMINISTRATOR IN THE STANDARD CONDITIONS OF CONTRACT

Every construction project activity may create its own unique set of requirement and circumstance. The different sectors including employer groups, contractors, suppliers, manufacturers, professionals have their own interests, which are very often divergent and competing in nature (Sundra, 1999). Standard form of construction contract offers several provisions clauses in relation to the roles and responsibilities for determination of roles and responsibilities of the employer, administrator and determination of contract by the contractor (Yong, 2006). According to the Hawkins (2011), the word 'determination' means the quality that makes you continue trying something to do something, even when this difficult or the process or deciding something official. In usual practice, contract administrator will be appointed from among the engineers and architects, (Singh, 2005) but this is depending on the type of contract document that applied. The comparison between standard forms of construction contract in terms of the roles and responsibilities of administrator is stated in the Standard Conditions of Contract as summarized below:

i. FIDIC $1^{\text {st }}$ edition RED BOOK - FIDIC defines the function of the engineer, where he is acting on behalf of the employer, and any decisions of matters in dispute are resolved by the Dispute Adjudication Board (DAB) (SubClause 20.4) rather than by the engineer (Sub-Clause 3.1: Engineer's Duties and Authority).

ii. PWD Form 203A (Rev.2007) - PWD defines the S.O.'s duties as being responsible for the overall supervision and directions of the works. The important decision on the Damages for Non-Completion (Clause 40), Delay and Extension of Time (Clause 43), Events and Consequences of Default by the Contractor (Clause 51), Termination on Corruption (Clause 53), Effect of Force Majeure (Clause 57) or Arbitration (Clause 65), where appropriate, is expressly reserved to the Appendix (usually a person more senior than the S.O) (Clause 3.0, 4.0 and 5.0). 
iii. PAM Contract 2006 - PAM provides for the Architect to Act as an independent certifier which is a typical type of private forms of contract. (Clause 2.0: Architect's Instruction).

Under the Agreement and Conditions of FIDIC, the contractual 'engineer' could be anyone designated as the engineer under the contract as an administrator of the contract. As per clause 1 in any standard form, the engineer and his representatives (assistants and inspectors named under FIDIC versions to represent the engineer) are two different persons. The engineer's representative is appointed by the employer to perform the duties delegated under another clause (clause 3 under new forms). It is the engineer who shall notify such an assignment of duties and delegation of authority to the contractor in writing indicating the extent of authority to act as the engineer's representative. This clause sets out the duties of the engineer's representative, basically to watch and supervise works, and test and examine materials to be used and workmanship employed in connection with the works. However, the engineer's representative has no authority to relieve the contractor of any duties or obligations under the contract, except as expressly provided in the contract, order any work involving delay or extra payment, and make any variation. The engineer also cannot amend the contract.

The engineer in FIDIC shall mean any person nominated to represent the employer. The engineer plays the role of employer's agent in protecting the employer's interests. In the event of the engineer being required in terms of his appointment by the employer to obtain the specific approval of the employer for the execution of any part of his functions or duties, such requirement shall be usually set out in the particular conditions. Any written instruction or approval given by the engineer's representative to the contractor within the terms of such delegation shall bind the contractor and the employers though it had been given by the engineer. However, any failure of the engineer's representative to disapprove the work or material does not harm the engineer's power to subsequently order pulling down, removed or breaking up such work or material of inferior quality.

The PWD 203A (Rev. 10/83) obliges the employer to appoint the S.O. who is responsible for the administration of a contract. Figure 1 represents the contractual relationship of the parties in the PWD 203A (Rev. 10/83). The contract is made between the government and the contractor. However, the government and the contractor are not allowed to make direct communication with each other can be shown in Figure 1. Under PWD203A, there are only provisions for determination by the employer (JKR, 1988).

Figure 1: Contractual relationship in PWD 203A (Rev. 10/83)

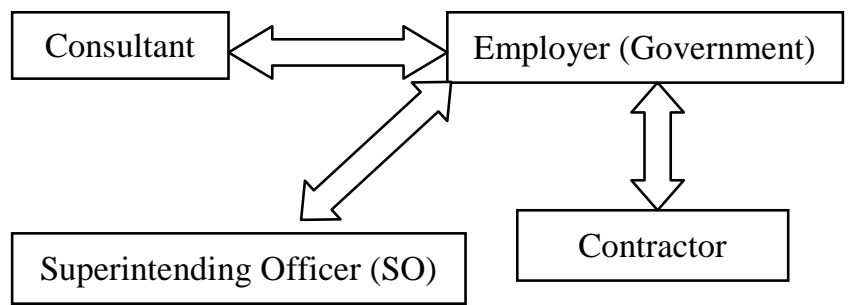

S.O. as contained in the contracts are as supervision, monitoring progress and report project sites, advance payment, interim certificates and deduction of withholding tax (if any), assessment of variation and final accounts, extension of time, project completion, handover project and defect, a certificate of completion does not work, sub-contractor is named, and termination of employment of the contractor.

The government or the contractor must always communicate through the S.O. Thus, in reality, the communication relationships in a contract between the S.O. and the contractor and the S.O. and the consultants employed by the government can be shown in Figure 2. Throughout the contract, both parties' intentions are supposed to be impartial judged by the S.O. The S.O., as an independent professional, is supposed to act impartially on both parties.

Figure 2: Communication relationship in PWD 203A (Rev. 10/83)

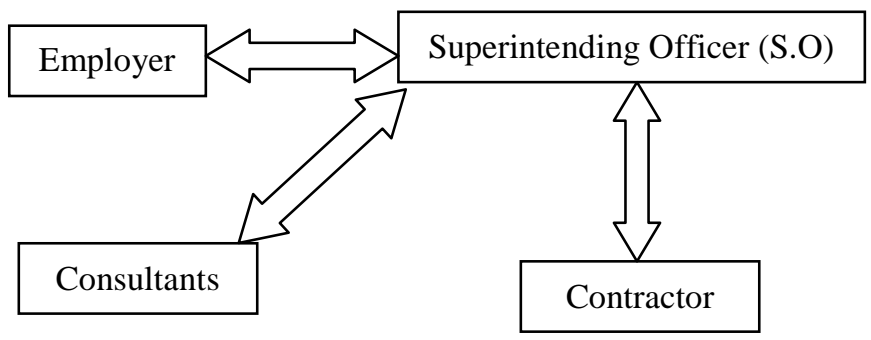

According to PWD203A, the impartiality of the S.O. is not always guaranteed (Umi Kalsum, 2008). Under the present system in Malaysia, the S.O. (in almost all cases) is appointed based on public post but not based on expertise and experience (Umi Kalsum, 2008). Moreover, the S.O is a civil servant. In such conditions, the S.O is likely to have a heavy burden to play dual roles to act on behalf of the government and to act impartially. Nevertheless in reality, the force which makes the S.O. impartial may be controlled by his/her professionalism and religious belief. The contractor's reaction to the S.O.'s impartiality may also function to make the S.O. impartial, because the S.O.'s decisions would make the contractor generate many disputes, which might finally be followed by a great amount of dispute cost. On the other hand, the causes of project delays fluctuate according to and due to the faults and weaknesses of the owner and the contractor (Zarabizan et al. 2013).

Under Agreement and Conditions of Building Contract PAM 2006 (With or Without Quantities), amongst the functions and responsibilities of an architect, architect plays an important role in supervising and administrating the building contract. The Architect in this capacity plays dual roles. $\mathrm{He} / \mathrm{she}$ is the employer's agent that the gives effect to his client's requirements. Concurrently, he/she is also an independent decision maker in the issuance of various certificates under the building contract. In this latter function, the architect is expected to be impartial land fair to both the employer and the contractor. An understanding of construction law is useful for the competent administration of the building contract (Thurai Das Thuraisingam, 2010). The Professional Architect is also required to supervise the work of actual 
construction to ensure it complies with intentions, standard of workmanship and quality in accordance with the contract (Sundra Rajoo, 1999).

The name of the Professional Architect and the name of their practice and address are to be stated in Articles 3. Article 7 defines 'Architect' as the person, named in Article 3, and shall be a Professional Architect or any other form of practice registered under the Architects Act 1967 and approved by the Board of Architects, Malaysia (BAM) (PAM, 2006). Under the Agreement and Conditions of Building Contract PAM 2006 (With or Without Quantities), there are certain powers given and duties to issue only (Umi Kalsum, 2008). These include the power and duty to issue and certify Architect Instruction, Submission to Local Authority, Variations, Extensions of Time, Loss and Expense as well as Certificates and Payment. The Professional Architect may perform functions as the agent or as impartial certifier. He may also do things which incur a duty under the law of tort to other persons. Therefore, it will depend largely on the professionalism and integrity of the Professional Architects. Professional Architect must carry their duties with due care and diligence (Sundra Rajoo, 2010).

\section{FINAL ACCOUNT IN CONSTRUCTION PROJECT}

The process payment to contractors begins from the start of construction until the project is completed. Among payments involved are advances payment, progress payment and final payment, which is the final figure of a contract project (Zarabizan et al. 2012b). Final accounts for the construction project have been prepared to show the final cost of a project that has been completed by the contractor (Wood et al. 1963). Final accounts include the cost of defect liability period, all additions, alternations, deductions resulting from project changes and other related payment as stated in the contract. Final accounts should be prepared immediately after the projects was completed based on the type condition of contract (PWD, 2010). Sometimes, it also refers to the calculation and agreement of the final construction cost between the employer, contractor and incorporates a fair valuation of the works carried out (Ashworth and Hogg, 2002).

Forms of contract to be used should be understood by all parties involved in the construction projects to prevent any disputes or problems in the future, especially in the closing of final accounts. Most of the standard forms of contract in Malaysia contain provisions upon which the contract administrator is obliged to closing the final account and issue a final payment certificate to the contractor within a stipulate time period after receipt of the contractor's final account statement (Zarabizan et al., 2012a and PWD, 2010).

On the other hand, impacts of problems in the closing of final account also represent an additional cost to the contractor where in majority of cases, the employer is anxious to know his ultimate financial commitment (Zarabizan et al. 2012a). The contract administrator has a contractual responsibility under the contract to ensure the date stipulated in the contract for completion of the final account is achieved, whilst the contractor should assist in giving prompt provision for subcontractor's and supplier's accounts by taking into account the method of measurement and prices based on agreement as well as providing necessary supporting data. Thus, this paper proposes a list of causes of problems in final account closing which is shown on Figure 3, as occur from the aspect of contract administrator issue.

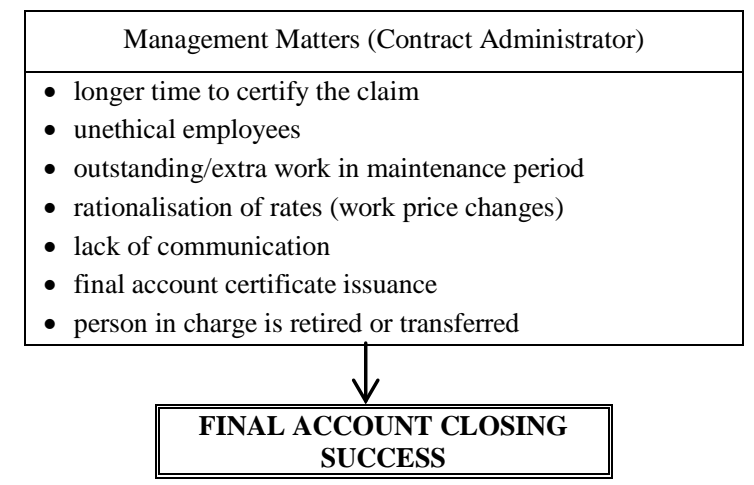

Figure 3: The important factors affecting final account closing success caused by contract administrator

(Source: Zarabizan et al. (2012)

In summary, contract administrator should give reminder to all parties to keep all the records properly. It is also clear that the preparation of proper record information at early stage should be done to avoid the problems of dispute and delay in the closing of final account. By doing this, it can reduce and avoid problems in the closing of final account after the defect liability period.

\section{CONCLUSIONS}

It is understood that, when a project is initiated by an employer/owner, all the duties related to feasibility, design and supervision during the construction time of the project are entrusted to an independent consulting who is called "engineer" in FIDIC conditions of contract, 'Superintending Officers in PWD 203A conditions of contract and 'Architect' between the Owner and Contractor in PAM2006 conditions of contract. One of the advantages of FIDIC conditions is that it has become a standard international form where an agreement has been approved and made public by a prestigious body such as architects, engineers, contractors. PWD203A and PAM 2006 forms are home based form where risks are known to be local industry and there is a much greater knowledge available in this regard. The major difference is in the function of the Engineer where FIDIC defines it as acting on behalf of the employer/owner, whilst PWD203A defines S.O's duties as being responsible for the overall supervision and direction of the works. The important decisions on EOT, LAD's and termination financial limit on variations have been being retained by the officer named in the Appendix (usually a person more senior than the S.O). PAM provides the architects to act as an independent certifier or administrator contract which is typical of private forms of contract.

Hence, this paper has successfully determined in detail the type forms of contract that have been used in the construction industry in Malaysia. This paper can greatly contribute to the implementation of a project by providing detailed information 
about contents forms of contract used in the construction industry in Malaysia. This paper successfully investigates the differences between forms of contract and also describes the roles and responsibilities the parties appointed as the contract administrator. The understanding of these roles and responsibilities is important at the preliminary stage especially in selecting superintending party as well as identifying the contract liability in the persuasion of the contract. Understanding at an early stage can guarantee and help in ensuring that the project can be completed on time, the project is completed in accordance with specified costs and preventing the occurrence of disputes. On the other hand, contract administrator should give reminder to all parties to keep all the records properly (Zarabizan et al. 2012). By doing this, it can reduce and avoid problems in the closing of final account after the defect liability period. Surely when the the project successfully completed, it will give the best view to the world with the ability to the country on managing the construction contract and eventually can attract foreign investors to invest.

As an important contribution, this paper has successful demontrated the criteria to be considered for selected Contract Administrator is specified in Figure 4. It is believed that the information of this paper can be immense help the construction players (clients, contractors and consultants) and academicians. The construction players can better understand and make efforts to reduce the incidences of dispute. In the future, through comparative studies in other aspects, the reason why each characteristic of a contract form, and roles and responsibilities contract administrator have been formed must be proven from the viewpoints of history, culture and business practices.

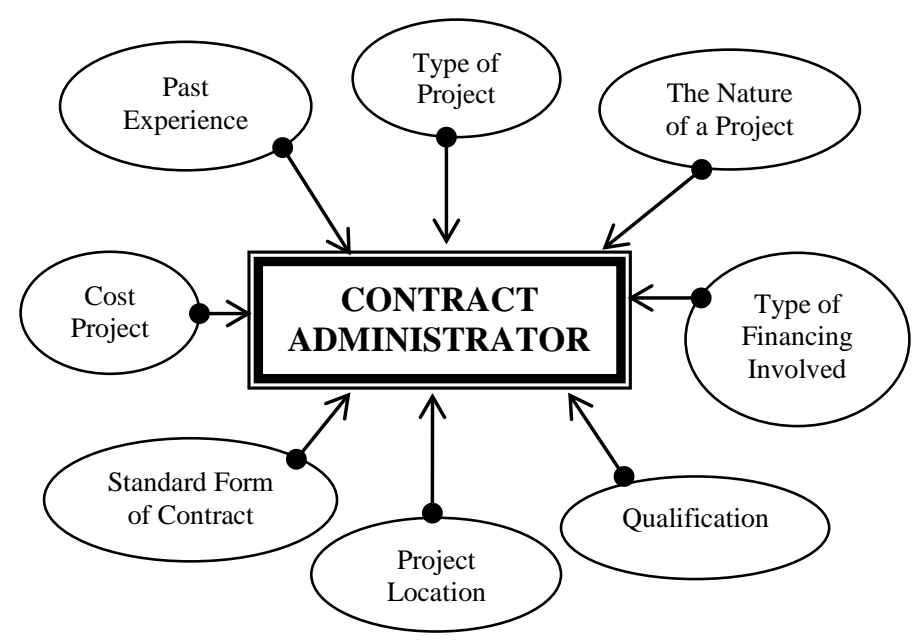

Figure 4: Contract Administrator Criteria

\section{ACKNOWLEDGMENT}

The authors would like to express their sincere gratitude to Ministry of Education and University of Technology Malaysia for providing the financial support for this paper to publish. Many thanks to Public Works Department Malaysia,
Construction Industry Development Board (CIDB), consultant and contractors who kindly participate the short discussions and interviews. The authors are also very grateful to the anonymous reviewers for their valuable comments to this paper. The study is financed by the Grant for Research University (GUP) of the University of Technology Malaysia, Johor for research funding under Cost Centre No. Q.K.130000.7140.00H47.

\section{REFERENCES}

[1] Abdalla, M.O., \& Hussien, T. B. (2001). Causes of construction delay: traditional contracts. International Journal of Project Management, 20(1), pp.67-73.

[2] Ashworth. A. (1991). Contractual procedures in the construction industry. (2nd ed.). London: Longman.

[3] Beresford Hartwel, G.M. (2008). Overview of the FIDIC Contract. UK: The national academy for dispute resolution Ltd.

[4] Broome, J. C., \& Hayes, R.W. (1997). A Comparison of the Clarity of Traditional Construction Contracts and of the New Engineering Contract. International Journal of Project Management, 15, 255-261.

[5] Cheung, S.O. (1999). Critical Factors Effecting the Use of Alternative Dispute Resolution Process in Construction. International Journal of Project Management, 17(3), 189-194.

[6] Cherns, A.B., \& Bryant, D.T. (1984). Studying the client's role in construction management. Journal of Construction Management and Economics, 2(2), pp.177-194.

[7] Che Rozilawani, C.A. (2003). Kajian Penamatan Kontrak Oleh JKR. M.Sc. Thesis. Universiti Teknologi Malaysia, Skudai.

[8] Construction Industry of Development Board Malaysia (CIDB). (2005). Best Practice Guideline C2: Choosing an appropriate form of contract for engineering and construction works. ( $2^{\text {nd }}$ ed.). Kuala Lumpur: CIDB Publication, (pp.3).

[9] Fahime, T., Zuhairuse, M.D., \& Muhammad Farihan, I.M. (2011). An Overview of Comparison between Parties of Construction Contracts in Malaysia. European Journal of Scientific Research, 49(3), pp.415-420.

[10] International Federation of Consulting Engineers (FIDIC). (1999). Conditions of contract for construction. Switzerland: FIDIC Publication.

[11] Harbans Sigh K.S. (2005). Construction Contracts: An Overview. The Ingenieur, pg.7.

[12] Harmon, K.M.J. (2003). Resolution of Construction Disputes: A Review of Current Methodologies. Journal of Leardership and Management in Engineering, 3(4), pp.187-201.

[13] Hawkins, J.M. (2011). Oxford Fajar Dictionary. (5 ${ }^{\text {th }}$ ed.). Kuala Lumpur: Oxford Fajar Sdn. Bhd.

[14] Hellard, B.R. (1997). Preventing and Solving Contruction Disputes, Litton Educational Publishing Company, New York.

[15] Hillebrandt, P.M. (2004). Economic Theory and the Construction Industry. (3 ed.). London: Macmillan.

[16] Iyer, K.C., Chaphalkar, N.B., \& Joshi., G.A. (2007). Understanding time delay disputes in construction contracts. International Journal of Project Management, 26(2), 174-184.

[17] Jabatan Kerja Raya (JKR) Malaysia. (1988). Guide on the Administration of Public Works Contracts. Kuala Lumpur: JKR Publication.

[18] Kaka, A., Wong, C., \& Fortune, C. (2008). Culture change through the use of appropriate pricing systems. Journal of Engineering, Construction and Architectural Management, 15(1), 66-77.

[19] Khairuddin, A.R. (2002). Construction Procurement in Malaysia, Processes and Systems. Master Project Management. International Islamic University, Malaysia.

[20] Fong, L.C. (2004). The Malaysian PWD Form of Construction Contract. London: Thomson Asia Pte Ltd.

[21] Low, S.P. (1994). Balancing construction and marketing in world economic development: the four global scenarios. Journal of Construction Management Economic, 12, 171-182.

[22] Malaysian International Building Exposition (MALBEX). (2005). Market watch - construction industry, Kuala Lumpur Exhibition Center Report. pp. 1-8. 
[23] Masamitsu, O., Khairuddin, A.R, Toshihiko. O., \& Kiyoshi, K. (2003). A Comparative Study on the Standard Forms of Contract in Malaysia and Japan with specific Refence to Variation Procedures. QS National Convention 2003. 18-19 August 2003. Sheraton Hotels and Towers, Subang Jaya, Selangor, Malaysia.

[24] Martin, E. (1993). Importance of Teaching Construction Specification. Professional Issue in Engineering Education and Practice, 119, pp.147-152.

[25] Mbacho, J., \& Nkado, R. (2007). Factors Constraining Successful Building Implementation in South Africa. Journal of Construction Management and Economic, 25(1), 39-54.

[26] Merrit, F.S, \& Ricketts, J.T. (2004). Building Design and Construction Handbook. New York: McGraw-Hill.

[27] Mitropoulos, P., \& Taum, C.B. (2000). Management-driven Integration. Journal of Management Engineering, 16(1), pp.48-58.

[28] Moavenzadeh, F., \& Janet Ann, K. R. (1975). The construction industry in developing countries. United States: Massachhusetts Institute of Technology Publication.

[29] Mohamad, I. M., \& Zulkifli, M. (2006). Undertanding Contract Documentation. Proceeding of the $6^{\text {th }}$ Asia-Pacific Structural Engineering and Construction Conference. September 5-6, 2006. APSEC, 2006. pp. C12-C18.

[30] Murali, S., \& Soon, Y.W. (2006). Causes and Effects of Delays in Malaysian Construction Industry. International Journal of Project Management, 25(1), pp.517-526.

[31] Murdoch, J., \& Hughes, W. (2000). Contraction Contracts - Law and Management. ( $3^{\text {rd }}$ Ed.). Great Britain: Spon Press.

[32] Mushtaq, A. S. (2007). Overview of The 1999 FIDIC Contract Forms and The Multilateral Developments Banks Contract. Proceedings of the Pakistan Engineering Congress 2007.

[33] Pertubuhan Akitek Malaysia (PAM). (2006). Agreement and Conditions of PAM Contract 2006 (with quantities). Kuala Lumpur: PAM Publication.

[34] Public Work Department Malaysia. (2007). PWD 203A Form of Contract Revised 2007: Standard Conventional Contract. Kuala Lumpur: PWD Publication.

[35] Public Work Department Malaysia (2007). Standard Form of Contract to Be Used where Bills of Quantities Form Part of the Contract P.W.D. Form 203A (Rev. 10/83). Kuala Lumpur: PWD Publication.

[36] Rubin, R.A, Fairweather, V., Guy, S.D., \& Maevis, A.C. (1992). Construction Claims: Prevention and Resolution. ( $2^{\text {nd }}$ ed.). New York: Van Nostrand Reinhold.

[37] Sundra Rajoo. (1999). The Malaysian Standard Form of Building Contract (the PAM 1998 Form). Malayan Law Journal, 2nd Edition, pp.3.

[38] Sundra Rajoo. (1999). The Malaysian Standard Form of Building Contract (The PAM 1998 Form). Malayan Law Journal, 2nd Edition, pp. 40.

[39] Sundra Rajoo. (2010). The PAM 2006 Standard Form of Building Contract - A Change in Risk Allocation. Malayan Law Journal, pg. Cxlvii.

[40] Thomas, H.R., Smith, G.R., \& Mellott, R.E. (1994). Interpretation of Construction Contract. Journal of Construction Engineering and Management (ASCE), 120(2), pp.321-336.

[41] Thomas H.R., Smith G.R., \& Ponderlick, R.M. (1992). Resolving disputes based on misrepresentations. Journal of Construction Engineering and Management (ASCE), 118(3), pp.472-87.

[42] Thompson, R. M., Vorster, M. C., \& Groton. (2000). Inovations to Manage Disputes : DRB and NEC. Journal of Management in Engineering, 16(5), 51-59.

[43] Thurai, D.T. (2012). The Architect as Contract Administrator - A Legal Perpective. PAM CPD Seminar. 30 June 2012, Kuching, Sarawak.

[44] Tse, R.Y.C., \& Ganesan, S. (1997). Causal relationship between construction flows and GDP: evidence from Hong Kong. Journal of Construction Management Economic, 15, pp.371-376.

[45] Umi Kalsum, Z. (2000). Termination of Architect Engagement. Master Project Management. Universiti Teknologi Malaysia, Skudai.

[46] Whitfield, J. (1994). Conflicts in construction avoiding, managing, resolving. London: Macmillan.

[47] Wilkinson, S., \& Scofield, R. (2010). Management for the New Zealand Construction Industry. ( $2^{\text {nd }}$ Edition). New Zealand: Pearson Education New Zealand Ltd.
[48] Yogeswaran, K., Kumaraswamy, M. M., \& Miller, D.R.A. (1998). Claims for extensions of time in civil engineering projects. Journal of Construction Management and Economics, 16(3), pp.283-29.

[49] Yong, T. L. (2006). Determination of Contract by Employer in Construction Industry. Master Project Management. Universiti Teknologi Malaysia, Skudai.

[50] Zarabizan Zakaria, Syuhaida Ismail \& Aminah Md Yusof (2012) Cause and impact of dispute and delay the closing of final account in Malaysia construction industry, Journal of Southeast Asian Research, 2012.

[51] Zakaria, Z., Ismail, S., \& Yusof, A. M. (2013, April). Effectiveness of Pavement Management System and its Effects to the Closing of Final Account in Construction Project in Malaysia. In Journal of Physics: Conference Series (Vol. 423, No. 1, p. 012034). IOP Publishing.

\section{Creative Commons Attribution License 4.0 (Attribution 4.0 International, CC BY 4.0)}

This article is published under the terms of the Creative Commons Attribution License 4.0 https://creativecommons.org/licenses/by/4.0/deed.en US 